\title{
Classification of Leptospires of the Pyrogenes Serogroup Isolated from Cattle in Zimbabwe by Cross-Agglutinin Absorption and Restriction Fragment Length Polymorphism Analysis
}

\author{
SARA B. FERESU, ${ }^{1 *}$ CAROLE A. BOLIN,${ }^{2}$ HANS KORVER,${ }^{3}$ AND WIEPKO J. TERPSTRA ${ }^{3}$ \\ Department of Biological Sciences, University of Zimbabwe, Mount Pleasant, Harare, Zimbabwe ${ }^{1}$; Leptospirosis and \\ Mycobacteriosis Research Unit, National Animal Disease Center, Agricultural Research Service, U.S. Department \\ of Agriculture, Ames, Iowa 50010²; and N. H. Swellengrebel Laboratory of Tropical Hygiene,
} The Royal Tropical Institute, 1105 AZ Amsterdam, The Netherlands ${ }^{3}$

\begin{abstract}
Five strains of the genus Leptospira belonging to serogroup Pyrogenes were isolated from cattle slaughtered in Zimbabwe and subjected to cross-agglutinin absorption and restriction fragment length polymorphism analysis. One strain, SBF 2, represents a new genetic strain of serovar kwale, while another strain, SBF 49, is a new genetic strain closely related to serovar nigeria. Three strains belong to a new serovar for which the name mombe with reference strain SBF 20 is proposed. Restriction fragment length polymorphism analysis indicated that each of these three strains represents a different restriction polymorphism pattern group.
\end{abstract}

The group of strains of the genus Leptospira classified in serogroup Pyrogenes currently consists of 14 recognized serovars (18), with two other serovars being considered $(5,10)$. Most of the reference strains of these serovars were initially isolated from humans $(1-3,8,15,19,32,33)$ and wildlife $(13$, $24,25,27)$. Isolation of strains of serogroup Pyrogenes from the bovine species has been limited (6).

In Africa, titers to the Pyrogenes serogroup have been detected in cattle from Uganda (4), in goats and sheep in the Sudan (26), and in humans in Nigeria (9). Strains of serogroup Pyrogenes have been isolated in Kenya and Nigeria. The reference strain of serovar kwale was isolated from a boy in Kenya (8) while that for the proposed serovar nigeria was isolated from cattle slaughtered at Jos abattoir in Nigeria (10). Diallo and Dennis (6) also isolated strains of serovar pyrogenes from kidneys of cattle in Zaria, Nigeria.

Leptospires are usually well adapted to a particular host with which they establish a commensal relationship. The natural hosts form an infection reservoir in which the leptospiral population is maintained. Leptospires may also be transmitted by their natural hosts to other animals or man with whom the reservoirs share the same ecological niche. In this way, other animals and man may then become accidental hosts, as the infecting leptospires are not adapted to the host and cannot colonize their kidneys. The leptospires are usually pathogenic to these accidental hosts.

Leptospires are usually characterized by a particular antigenic structure in the natural host-leptospire relationship. This structure is defined by using the cross-agglutinin absorption tests (CAAT), the results of which form the basis of the serovar concept (7). The serovar concept is still applicable in many situations but is not always fully satisfactory, as it may delineate artificially closely related strains on one hand while failing to distinguish between antigenically similar strains that have different ecological niches on the other hand. In addition, genetic analyses have demonstrated that antigenically and thus phenotypically similar strains may be genetically very diverse $(14,22,34)$. Conversely, genetically analysis has sometimes

\footnotetext{
* Corresponding author. Mailing address: Department of Biological Sciences, University of Zimbabwe, MP167, Mount Pleasant, Harare, Zimbabwe. Phone: 263-4-303211. Fax: 263-4-333407.
}

failed to differentiate between antigenically different strains $(28,30,35)$.

On the subspecies level, serology, based on antigenic traits, is still the recognized and generally accepted method for classification for members of the genus Leptospira. The CAAT, the basic method, is however, time-consuming and difficult. Recently, a variety of modern methods for genetic analysis have become available $(14,17,20-22,34)$. Although useful, these methods have failed so far to present a coherent picture which would allow for the development of a natural and logic classification system based on genetic traits. In this respect, it must be stressed that the splitting up of pathogenic leptospires from one into seven species on the basis of hybridization experiments $(22,34)$, is so far mainly of academic interest. As far as practical epidemiology is concerned, little has changed with regard to the monospecies situation. The differences revealed by hybridization experiments so far are still too crude to describe the desired host-leptospire relationships. In addition, the techniques for hybridization are still too complicated to be performed outside a few highly specialized laboratories, a fact which emphasizes the lack of consequence of speciation for the purpose of contributing to practical typing at the subspecies level. A classification system based on genetic traits should be refined to allow for subspecies characterization and should be easy to carry out in terms of the needs of practical epidemiology. Once this system is developed, it should give useful additional information, as antigenically similar strains may belong to different species $(14,22,34)$.

It is our opinion that pending the development of a new classification system and new typing methods, leptospires should be issued a serovar status and be typed by the recognized standard method, the CAAT (7). The CAAT should be complemented by a genetic method in order to generate necessary additional information, notably for cases in which the serology test fails to differentiate between genetically different leptospires. Restriction fragment length polymorphism analysis (RFLP) is the method of choice to obtain additional information, as most reference strains have already been examined by this method and the bulk of the information is readily available (29). So far, results of RFLP have often confirmed the differences that exist between serovars $(16,23)$.

The isolation and serogrouping of five strains belonging to serogroup Pyrogenes from Zimbabwe beef cattle have been 
TABLE 1. CAAT results among Zimbabwean strains and antisera

\begin{tabular}{|c|c|c|c|c|c|c|}
\hline \multirow{3}{*}{ Antiserum } & \multirow{3}{*}{$\begin{array}{l}\text { Absorbing } \\
\text { strain }\end{array}$} & \multicolumn{4}{|c|}{ Reciprocal of titer } & \multirow{3}{*}{$\begin{array}{l}\text { Reciprocal of homologous } \\
\text { titer (\% of unabsorbed } \\
\text { serum titer) }\end{array}$} \\
\hline & & \multicolumn{2}{|c|}{ Before absorption } & \multicolumn{2}{|c|}{ After absorption } & \\
\hline & & $\begin{array}{l}\text { Homologous } \\
\text { strain }\end{array}$ & $\begin{array}{l}\text { Absorbing } \\
\text { strain }\end{array}$ & $\begin{array}{l}\text { Homologous } \\
\text { strain }\end{array}$ & $\begin{array}{l}\text { Absorbing } \\
\text { strain }\end{array}$ & \\
\hline SBF 2 & SBF 20 & 12,800 & 3,200 & 6,400 & 0 & 50 \\
\hline SBF 20 & SBF 2 & 6,400 & 1,600 & 3,200 & 0 & 50 \\
\hline SBF 2 & SBF 28 & 12,800 & 1,600 & 6,400 & 0 & 50 \\
\hline SBF 28 & SBF 2 & 6,400 & 800 & 3,200 & 0 & 50 \\
\hline SBF 2 & SBF 43 & 12,800 & 800 & 6,400 & 0 & 50 \\
\hline SBF 43 & SBF 2 & 6,400 & 1,600 & 3,200 & 0 & 50 \\
\hline SBF 2 & SBF 49 & 12,800 & 3,200 & 6,400 & 200 & 50 \\
\hline SBF 49 & SBF 2 & 25,600 & 1,600 & 12,800 & 100 & 50 \\
\hline SBF 20 & SBF 28 & 6,400 & 6,400 & 400 & 200 & 6.25 \\
\hline SBF 28 & SBF 20 & 6,400 & 6,400 & 100 & 100 & 1.6 \\
\hline SBF 20 & SBF 43 & 6,400 & 6,400 & 200 & 200 & 3.1 \\
\hline SBF 43 & SBF 20 & 6,400 & 6,400 & 100 & 100 & 1.6 \\
\hline SBF 20 & SBF 49 & 6,400 & 3,200 & 6,400 & 0 & 100 \\
\hline SBF 49 & SBF 20 & 12,800 & 3,200 & 6,400 & 100 & 50 \\
\hline SBF 28 & SBF 43 & 6,400 & 6,400 & 100 & 100 & 1.6 \\
\hline SBF 43 & SBF 28 & 6,400 & 6,400 & 200 & 200 & 3.1 \\
\hline SBF 28 & SBF 49 & 6,400 & 1,600 & 3,200 & 100 & 50 \\
\hline SBF 49 & SBF 28 & 12,800 & 1,600 & 12,800 & 100 & 100 \\
\hline SBF 43 & SBF 49 & 6,400 & 3,200 & 3,200 & 0 & 50 \\
\hline SBF 49 & SBF 43 & 12,800 & 800 & 6,400 & 0 & 50 \\
\hline
\end{tabular}

described previously (11). This paper describes the identification of these strains to the serovar level, which was accomplished by using the CAAT and RFLP analysis of their genomic DNA.

\section{MATERIALS AND METHODS}

Antisera from reference strains of the 14 recognized and the 2 proposed serovars belonging to serogroup Pyrogenes ( $a b r a-$ mis, alexi, biggis, camlo, guaratuba, hamptoni, kwale, manilae, menglian, myocastoris, nigeria, princestown, pyrogenes, robin- soni, varela, and zanoni) and from the isolates, for use in the CAAT, were produced in paired rabbits and pooled before use as previously described (12). Reference strains (18) were used, except for serovar varela for which strain LT 992 was substituted for strain LT 1019. The reference strains are part of the reference collections at either the National Reference Laboratory, National Animal Disease Center (Ames, Iowa), or the World Health Organization-Food and Agriculture Organization Leptospirosis Reference Laboratory (Amsterdam, The Netherlands).

The five Pyrogenes isolates from Zimbabwe beef cattle were

TABLE 2. Serovar identification of strain SBF 2 by CAAT

\begin{tabular}{|c|c|c|c|c|c|c|}
\hline \multirow{3}{*}{ Antiserum } & \multirow{3}{*}{$\begin{array}{l}\text { Absorbing } \\
\text { strain or } \\
\text { serovar }\end{array}$} & \multicolumn{4}{|c|}{ Reciprocal of titer } & \multirow{3}{*}{$\begin{array}{l}\text { Reciprocal of homologous } \\
\text { titer (\% of unabsorbed } \\
\text { serum titer) }\end{array}$} \\
\hline & & \multicolumn{2}{|c|}{ Before absorption } & \multicolumn{2}{|c|}{ After absorption } & \\
\hline & & $\begin{array}{l}\text { Homologous } \\
\text { strain }\end{array}$ & $\begin{array}{l}\text { Absorbing } \\
\text { strain }\end{array}$ & $\begin{array}{l}\text { Homologous } \\
\text { strain }\end{array}$ & $\begin{array}{c}\text { Absorbing } \\
\text { strain }\end{array}$ & \\
\hline SBF 2 & hamptoni & 6,400 & 1,600 & 3,200 & 0 & 50 \\
\hline hamptoni & SBF 2 & 6,400 & 3,200 & 1,600 & 100 & 25 \\
\hline SBF 2 & kwale & 6,400 & 6,400 & 100 & 0 & 1.6 \\
\hline kwale & SBF 2 & 12,800 & 3,200 & 400 & 0 & 3.1 \\
\hline SBF 2 & pyrogenes & 6,400 & 1,600 & 6,400 & 100 & 100 \\
\hline pyrogenes & SBF 2 & 6,400 & 3,200 & 3,200 & 100 & 50 \\
\hline SBF 2 & robinsoni & 6,400 & 1,600 & 3,200 & 100 & 50 \\
\hline robinsoni & SBF 2 & 6,400 & 3,200 & 1,600 & 100 & 25 \\
\hline
\end{tabular}


TABLE 3. Serovar identification of strain SBF 49 by CAAT

\begin{tabular}{|c|c|c|c|c|c|c|}
\hline \multirow{3}{*}{ Antiserum } & \multirow{3}{*}{$\begin{array}{l}\text { Absorbing } \\
\text { strain or } \\
\text { serovar }\end{array}$} & \multicolumn{4}{|c|}{ Reciprocal of titer } & \multirow{3}{*}{$\begin{array}{l}\text { Reciprocal of homologous } \\
\text { titer (\% of unabsorbed } \\
\text { serum titer) }\end{array}$} \\
\hline & & \multicolumn{2}{|c|}{ Before absorption } & \multicolumn{2}{|c|}{ After absorption } & \\
\hline & & $\begin{array}{l}\text { Homologous } \\
\text { strain }\end{array}$ & $\begin{array}{l}\text { Absorbing } \\
\text { strain }\end{array}$ & $\begin{array}{l}\text { Homologous } \\
\text { strain }\end{array}$ & $\begin{array}{l}\text { Absorbing } \\
\text { strain }\end{array}$ & \\
\hline SBF 49 & alexi & 25,600 & 3,200 & 12,800 & 0 & 50 \\
\hline alexi & SBF 49 & 3,200 & 1,600 & 400 & 0 & 6.2 \\
\hline SBF 49 & hamptoni & 25,600 & 3,200 & 25,600 & 100 & 100 \\
\hline hamptoni & SBF 49 & 3,200 & 6,400 & 3,200 & 0 & 100 \\
\hline SBF 49 & kwale & 51,200 & 12,800 & 25,600 & 200 & 50 \\
\hline kwale & SBF 49 & 12,800 & 3,200 & 1,600 & 0 & 12.5 \\
\hline SBF 49 & nigeria & 25,600 & 12,800 & 3,200 & 100 & 12.5 \\
\hline nigeria & SBF 49 & 6,400 & 6,400 & 100 & 0 & 1.6 \\
\hline SBF 49 & pyrogenes & 51,200 & 3,200 & 25,600 & 100 & 50 \\
\hline pyrogenes & SBF 49 & 6,400 & 6,400 & 12,800 & 200 & 200 \\
\hline SBF 49 & robinsoni & 51,200 & 1,600 & 25,600 & 100 & 50 \\
\hline robinsoni & SBF 49 & 3,200 & 6,400 & 1,600 & 100 & 50 \\
\hline
\end{tabular}

labelled SBF 2, SBF 20, SBF 28, SBF 43, and SBF 49. These isolates and their antisera were tested in reciprocal tests against each other and against the reference strains and antisera of the serogroup Pyrogenes.

All the Zimbabwean isolates were cross-absorbed against each other's antisera. Only those reference strains which had a reciprocal agglutination titer of at least $1: 1,600$ with the isolates were used in CAAT. CAAT were performed by the Bratislava technique as described by Dikken and Kmety (7), and the results were confirmed by the Amsterdam laboratory.

The RFLP patterns of the five Zimbabwe strains (SBF 2, SBF 20, SBF 28, SBF 43, and SBF 49) were compared with those of serogroup Pyrogenes serovar alexi, camlo, hamptoni, kwale, nigeria, princestown, pyrogenes, and robinsoni reference strains. Selection of these serovars was based on the results of the CAAT. Bacterial chromosomal DNA extraction, restriction endonuclease digestion, gel electrophoresis, and photography were carried out as described by Thiermann et al. (30).

\section{RESULTS}

Isolates are considered members of a serogroup if they react to at least $6 \%$ of the homologous titer with sera from most members of the serogroup (7). All the five isolates reacted to this level with most members of the Pyrogenes serogroup, except for serovars guaratuba and varela with which they showed very little similarity. Strains SBF 2, SBF 20, SBF 28, SBF 43, and SBF 49 were identified as belonging to serogroup Pyrogenes on this basis.

Two strains are considered to belong to different serovars if after cross-absorption with adequate amounts of heterologous antigen, $10 \%$ or more of the homologous titer regularly remains in at least one of the two antisera in repeated tests (7). The results demonstrated that the SBF strains belong to three serovars, represented by strains $2 ; 20,28$ and 43 ; and 49 (Table 1).

Antisera of strains SBF 2 and SBF 49 both had a titer higher than $1: 1,600$ to reference strains representing serovar hamptoni, kwale, pyrogenes, and robinsoni. In addition, the antiserum of strain SBF 49 had high titers to the reference strains of serovar alexi and the proposed serovar nigeria.
The results of the CAAT with strain SBF 2 and the reference strains are shown in Table 2 and indicate that strain SBF 2 belongs to serovar kwale.

Strain SBF 49 showed a close relationship to the reference strain of the proposed serovar nigeria but had a titer a little above the $10 \%$ limit consistently remaining in at least one of the two antisera (Table 3). Therefore, on the basis of these results, strain SBF 49 is antigenically closely related to serovar nigeria strains.

Although CAAT were carried out with strains SBF 20, SBF 28 , and SBF 43, only the results for strain SBF 20, which had the broadest relationship with other Pyrogenes serogroup serovars, will be presented, and this strain will therefore be used as the reference strain for this subgroup. Strain SBF 20 was closely related to the serovars alexi, camlo, hamptoni, kwale, menglian, nigeria, princestown, pyrogenes, and robinsoni. It was therefore cross-absorbed with reference strains of these serovars (Table 4). The results indicate that strain SBF 20 is antigenically different from members of all previously described serovars of serogroup Pyrogenes. The three strains (SBF 20, SBF 28, and SBF 43) therefore represent a new serovar within serogroup Pyrogenes.

Each of the five isolates produced unique RFLP patterns when digested with the endonucleases EcoRI (Fig. 1) and HhaI (Fig. 2). Strain SBF 2 (lane 1) shows a pattern which is different from that of the reference strain for serovar kwale (lane 10). Strains SBF 20 (lane 2), SBF 28 (lane 3), and SBF 43 (lane 4) show differences among themselves and with all the reference strains. Strain SBF 49 (lane 5) also shows a pattern which is different from that of strains of the proposed serovar nigeria (lanes 6 to 8), with which it is serologically closely related.

\section{DISCUSSION}

Genetic analysis by RFLP has demonstrated again its power in marking clear distinctions between some Zimbabwean cattle isolates and between antigenically similar reference strains and isolates, with strain SBF 2 representing a new genetic type in serovar kwale and strain SBF 49 representing a new genetic type closely related to serovar nigeria. This is the first report of 
TABLE 4. CAAT results for strain SBF 20 with serovars from the Pyrogenes serogroup

\begin{tabular}{|c|c|c|c|c|c|c|}
\hline \multirow{3}{*}{ Antiserum } & \multirow{3}{*}{$\begin{array}{l}\text { Absorbing } \\
\text { strain or } \\
\text { serovar }\end{array}$} & \multicolumn{4}{|c|}{ Reciprocal of titer } & \multirow{3}{*}{$\begin{array}{l}\text { Reciprocal of homologou } \\
\text { titer (\% of unabsorbed } \\
\text { serum titer) }\end{array}$} \\
\hline & & \multicolumn{2}{|c|}{ Before absorption } & \multicolumn{2}{|c|}{ After absorption } & \\
\hline & & $\begin{array}{l}\text { Homologous } \\
\text { strain }\end{array}$ & $\begin{array}{c}\text { Absorbing } \\
\text { strain }\end{array}$ & $\begin{array}{c}\text { Homologous } \\
\text { strain }\end{array}$ & $\begin{array}{c}\text { Absorbing } \\
\text { strain }\end{array}$ & \\
\hline SBF 20 & alexi & 12,800 & 1,600 & 12,800 & 100 & 100 \\
\hline alexi & SBF 20 & 6,400 & 1,600 & 1,600 & 0 & 25 \\
\hline SBF 20 & camlo & 12,800 & 3,200 & 3,200 & 100 & 25 \\
\hline camlo & SBF 20 & 12,800 & 1,600 & 6,400 & 0 & 50 \\
\hline SBF 20 & hamptoni & 12,800 & 1,600 & 6,400 & 100 & 50 \\
\hline hamptoni & SBF 20 & 3,200 & 3,200 & 1,600 & 100 & 50 \\
\hline SBF 20 & kwale & 12,800 & 3,200 & 3,200 & 100 & 25 \\
\hline kwale & SBF 20 & 3,200 & 1,600 & 800 & 0 & 25 \\
\hline SBF 20 & menglian & 12,800 & 3,200 & 6,400 & 100 & 50 \\
\hline menglian & SBF 20 & 25,600 & 6,400 & 12,800 & 100 & 50 \\
\hline SBF 20 & nigeria & 12,800 & 6,400 & 6,400 & 0 & 50 \\
\hline nigeria & SBF 20 & 6,400 & 1,600 & 3,200 & 0 & 50 \\
\hline SBF 20 & princestown & 12,800 & 3,200 & 6,400 & 100 & 50 \\
\hline princestown & SBF 20 & 12,800 & 800 & 3,200 & 0 & 25 \\
\hline SBF 20 & pyrogenes & 12,800 & 6,400 & 3,200 & 200 & 25 \\
\hline pyrogenes & SBF 20 & 12,800 & 1,600 & 3,200 & 100 & 25 \\
\hline SBF 20 & robinsoni & 12,800 & 3,200 & 6,400 & 100 & 50 \\
\hline robinsoni & SBF 20 & 12,800 & 1,600 & 6,400 & 100 & 50 \\
\hline
\end{tabular}

these two serovars in Zimbabwe. We were also able to identify a new serovar, mombe, represented by strain SBF 20, which is antigenically and genetically different from other serovars in the same serogroup. Within serovar mombe, we were able to demonstrate three different genetic types represented by isolates SBF 20, SBF 28, and SBF 43. We believe that all the isolates examined are now sufficiently characterized to allow further studies which, since this study records the second African country from which strains of serogroup Pyrogenes have been isolated from cattle, should address the key issue of whether cattle are natural hosts of these isolates in Africa. If cattle are only accidental hosts, these studies should determine the animal species to which the isolates are adapted.

Although the isolates examined in this study are now sufficiently characterized for practical purposes, once again the limitations of serological analysis have been illustrated. Clearly, subspecies classification of leptospires is at a crossroad. It is regrettable that the present state of technological development does not yet allow quick and easy determination of the species to which a leptospiral isolate belongs, as this might add to the elucidation of a still obscure natural subspecies classification system based on phylogenetically determined relationships. Pending new developments in genetic analysis of leptospires, serology is still the best method for initial typing, as even simple agglutination with conventional rabbit reference antisera can give quick results which may satisfy the demands of epidemiological practice in many situations. In addition, there might remain a place for antigenic analysis through serological methods even in the long term, since the phenotype might, in some cases, present the host-leptospire relationship more clearly than genetic analysis. RFLP analysis is a useful adjunct or often an alternative to serology. Results by this method are less quick and less easy to obtain than those of serology, but the advantage is that the method is widely available and not technically demanding and the results are easy to interpret when a data base of reference strains or their reference patterns is available.

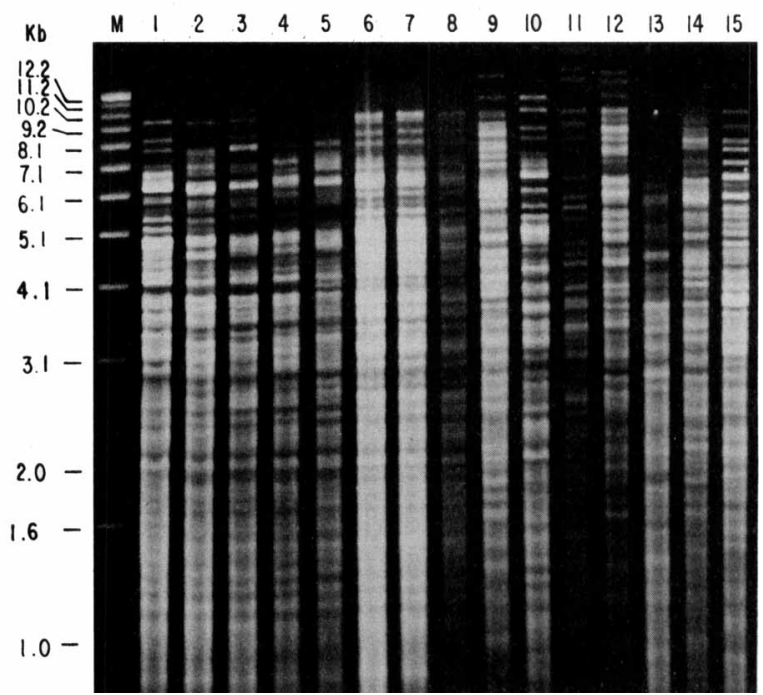

FIG. 1. RFLP patterns of chromosomal DNA from five Zimbabwe isolates and reference strains of serogroup Pyrogenes digested with EcoRI. Lanes: M, fragment size markers; 1, strain SBF 2; 2, strain SBF 20; 3, strain SBF 28; 4, strain SBF 43; 5, strain SBF 49; 6 to 8, three strains belonging to serovar nigeria, $\mathrm{v} 2 \mathrm{JA}, \mathrm{v} 33 \mathrm{JA}$, and vv4JA, respectively; 9 to 15 , reference strains belonging to serogroup Pyrogenes serovar pyrogenes, $k w a l e$, alexi, camlo, hamptoni, robinsoni, and princestown, respectively. 


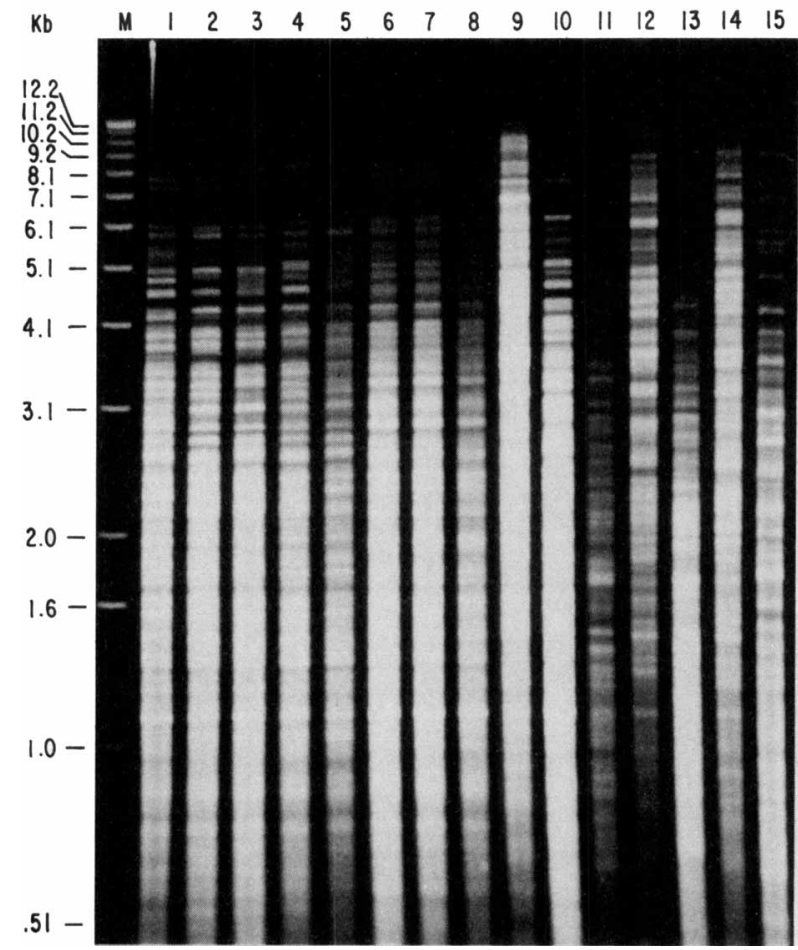

FIG. 2. RFLP patterns of chromosomal DNA from five Zimbabwe isolates and reference strains of serogroup Pyrogenes digested with Hhal. Lanes are identified in the legend to Fig. 1.

\section{ACKNOWLEDGMENTS}

We thank Annette Handsaker and John Foley for technical assistance and W. A. Ellis for providing the serovar nigeria isolates.

Isolation work was financed by grants from the University of Zimbabwe Research Board and the International Foundation for Science. The isolates were characterized at The Animal Disease Center, Ames, Iowa and The Royal Tropical Institute, Amsterdam, The Netherlands. S.B.F. was sponsored by Fogarty USA Public Service International Research Fellowship IF 05 TW 4154-01.

\section{REFERENCES}

1. Alexander, A. D., A. S. Benenson, R. J. Byrne, R. S. Diaz-Rivera, L. B. Evans, W. S. Gochenour, H. E. Hall, J. A. Hightower, H. Jeffries, J. De Jesus, E. Martinez, M. Paniagua, J. A. Pons, F. Ramos-Morales, R. Rodriguez-Molina, K. Y. Swisher, Jr., T. E. Woodward, and R. H. Yager. 1963. Leptospirosis in Puerto Rico. Zool. Res. 2:153-227.

2. Alexander, A. D., L. B. Evans, A. J. Toussaint, R. H. Marchwicki, and F. R. McCrumb, Jr. 1957. Leptospirosis in Malaya. II. Antigenic analysis of 110 leptospiral strains and other serologic studies. Am. J. Trop. Med. Hyg. 6:871-889.

3. Alexander, A. D., and D. J. W. Smith. 1962. Leptospira robinsoni, a new serotype of the Pyrogenes serogroup. Aust. J. Exp. Biol. 40:81-84.

4. Ball, M. G. 1966. Animal hosts of leptospires in Kenya and Uganda. Am. J. Trop. Med. Hyg. 15:523-530.

5. Cuizhi, L., L. Zhaohua, and G. Jiyuan. 1988. Identification of four new strains of Leptospira. Acta Microbiol. Sin. 28:173-178.

6. Diallo, A. A., and S. M. Dennis. 1982. Bacteriological survey of leptospirosis in Zaria, Nigeria. Trop. Geogr. Med. 34:29-34.

7. Dikken, H., and E. Kmety. 1978. Serological typing methods of leptospires. Methods Microbiol. 11:259-307.

8. Dikken, H., E. Kmety, A. De Geus, and V. E. A. Timmer. 1979. A new leptospiral serovar in the Pyrogenes serogroup. Trop. Geogr. Med. 31:405-408.

9. Ezeh, A. O., A. A. Adesiyun, P. B. Addo, J. O. Chukwuekezie, and
J. Tiyagnet. 1989. Prevalence of leptospiral antibodies among apparently healthy blood donors in Jos, Nigeria. Indian Vet. J. 66:4-8.

10. Ezeh, A. O., E. Kmety, W. A. Ellis, P. B. Addo, and A. A. Adesiyun. 1989. Characterisation of leptospires isolated from cattle and man in Plateau State, Nigeria. Rev. Sci. Tech. Off. Int. Epizoot. 8:1009-1020.

11. Feresu, S. B. 1992. Isolation of Leptospira interrogans from kidneys of Zimbabwe beef cattle. Vet. Rec. 130:446-448.

12. Feresu, S. B., and C. A. Bolin. 1991. Characterization of Leptospira interrogans isolated from cattle in Zimbabwe, p. 215-224. In Y. Kobayashi (ed.), Leptospirosis. Proceedings of the Leptospirosis Research Conference 1990. University of Tokyo Press, Tokyo.

13. Galton, M. M., P. R. Aragon, A. V. Jacalne, E. B. Shotts, Jr., and C. R. Sulzer. 1963. A new leptospiral serotype in the Pyrogenes group, Leptospira manilae. J. Infect. Dis. 112:164-166.

14. Gravekamp, C., H. Van de Kemp, M. Franzen, D. Carrington, G. J. Schoone, G. J. J. M. Van Eys, C. O. R. Everard, R. A. Hartskeerl, and W. J. Terpstra. 1993. Detection of seven species of pathogenic leptospires by PCR using two sets of primers. J. Gen. Microbiol. 139:1691-1700.

15. Green, A. E., C. R. Sulzer, C. O. R. Evarard, and W. L. Jones. 1978. Four new leptospira serotypes from Trinidad. West Indian Med. J. 27:117-126.

16. Hathaway, S. C., R. B. Marshall, T. W. A. Little, S. A. Headlam, and P. J. Winter. 1985. Differentiation of reference strains of leptospires of the Pomona serogroup by cross-agglutination absorption and restriction endonuclease analysis. Res. Vet. Sci. 39:145-150.

17. Herrmann, J. L., E. Bellenger, P. Perolat, G. Baranton, and I. Saint Girons. 1992. Pulse-field gel electrophoresis of NotI digests of leptospiral DNA: a new rapid method of serovar identification. J. Clin. Microbiol. 30:1696-1702.

18. Kmety, E., and H. Dikken. 1988. Revised list of Leptospira serovars. International Committee on Systematic Bacteriology of the International Union of Microbiological Societies Subcommittee on the Taxonomy of Leptospira. University Press, Groningen, The Netherlands.

19. Lumley, G. F. 1937. Leptospirosis in Queensland: a serological investigation leading to the discovery of distinct serological groups of Leptospirae causing leptospirosis as it occurs in Northern Queensland, with some other related observations. Med. J. Aust. 24:654-664.

20. Pérolat, P., F. Grimont, B. Regnault, P. A. D. Grimont, E. Fournié, H. Thevenet, and G. Baranton. 1990. rRNA gene restriction patterns of Leptospira: a molecular typing system. Res. Microbiol. 141:159-171.

21. Pérolat, P., I. Lecuyer, D. Postic, and G. Baranton. 1993. Diversity of ribosomal DNA fingerprints of Leptospira serovars provides a database for subtyping and species assignation. Res. Microbiol. 144:5-15.

22. Ramadass, P., B. D. W. Jarvis, R. J. Corner, D. Penny, and R. B. Marshall. 1992. Genetic characterization of pathogenic Leptospira species by DNA hybridization. Int. J. Syst. Bacteriol. 42:215-219.

23. Robinson, A. J., P. Ramadass, A. Lee, and R. B. Marshall. 1982. Differentiation of subtypes within Leptospira interrogans serovars hardjo, balcanica and tarassovi, by bacterial restriction-endonuclease DNA analysis (BRENDA). J. Med. Microbiol. 15:331-338.

24. Roth, E. E., W. V. Adams, B. Greer, G. E. Sanford, M. Moore, and K. Newman. 1963. New leptospiral serotype in the Pyrogenes serogroup. Public Health Rep. 78:727-730.

25. Santa Rosa, C. A., C. R. Sulzer, W. Giorgi, A. S. da Silva, R. M. Yanaguita, and A. O. Lobao. 1975. Leptospirosis in wildlife in Brazil: isolation of a new serotype in the Pyrogenes group. Am. J. Vet. Res. 36:1363-1365.

26. Shigidi, M. T. A. 1974. Animal leptospirosis in the Sudan. Br. Vet. J. 130:528-531.

27. Sulzer, K., V. Pope, and F. Rogers. 1982. New leptospiral serotypes (serovars) from the Western Hemisphere isolated during 1964 through 1970. Rev. Latinoam. Microbiol. 24:15-17.

28. Tamai, T., E. Sada, and Y. Kobayashi. 1988. Restriction endonuclease DNA analysis of Leptospira interrogans serovars icterohaemorrhagiae and copenhageni. Microbiol. Immunol. 32:887-894. 
29. Terpstra, W. J. 1992. Typing Leptospira from the perspective of a reference laboratory. Acta Leiden. 60:79-87.

30. Thiermann, A. B., A. L. Handsaker, J. W. Foley, F. H. White, and B. F. Kingscote. 1986. Reclassification of North American leptospiral isolates belonging to serogroups Mini and Sejroe by restriction endonuclease analysis. Am. J. Vet. Res. 47:61-66.

31. Thiermann, A. B., A. L. Handsaker, S. L. Moseley, and B. Kingscote. 1985. New method for classification of leptospiral isolates belonging to serogroup Pomona by restriction endonuclease analysis: serovar kennewicki. J. Clin. Microbiol. 21:585-587.

32. Tsai, C. C., and C. R. Sulzer. 1971. Four new leptospiral serotypes isolated from human sources in South Vietnam. Southeast Asian J.
Trop. Med. Public Health 2:313-321.

33. Vervoort, H. 1923. Spirochaeten bij acute koortsige ziekten van onbekenden oorsprong in de tropen. Spirochaetosis febrilis. Geneeskd. Tijdschr. Nederlansch-Indie 63:800-839.

34. Yasuda, P. H., A. G. Steigerwalt, K. R. Sulzer, A. F. Kaufmann, F. Rogers, and D. J. Brenner. 1987. Deoxyribonucleic acid relatedness between serogroups and serovars in the family Leptospiraceae with proposals for seven new Leptospira species. Int. J. Syst. Bacteriol. 37:407-415.

35. Zuerner, R. L., and C. A. Bolin. 1990. Nucleic acid probe characterizes Leptospira interrogans serovars by restriction fragment length polymorphisms. Vet. Microbiol. 24:355-366. 